\title{
A New Tiny Kalophrynus (Amphibia, Anura, Microhylidae) from Northern Sarawak, Malaysian Borneo
}

$\operatorname{AUTHOR}(S)$ :

Matsui, Masafumi; Nishikawa, Kanto

\section{CITATION:}

Matsui, Masafumi ... [et al]. A New Tiny Kalophrynus (Amphibia, Anura, Microhylidae) from Northern Sarawak, Malaysian Borneo. Current Herpetology 2011, 30(2): 145-153

\section{ISSUE DATE:}

2011-12

URL:

http://hdl.handle.net/2433/216838

RIGHT:

(C) 2011 by The Herpetological Society of Japan 


\title{
A New Tiny Kalophrynus (Amphibia, Anura, Microhylidae) from Northern Sarawak, Malaysian Borneo
}

\author{
MASAFUMI MATSUI* AND KANTO NISHIKAWA
}

Graduate School of Human and Environmental Studies, Kyoto University, Kyoto 606-8501, JAPAN

\begin{abstract}
A new microhylid frog is described from Bario, Kelabit Highlands of the State of Sarawak, in the Eastern Malaysia of Borneo Island. Morphologically, the new species differs from all known congeners in the combination of small body size; short fourth finger without subarticular tubercle; absence of subarticular tubercles on fifth toe, and usually on first finger; presence of light lateral stripe and dark inguinal spot; absence of nuptial pads and outer metatarsal tubercles. Acoustically, the new species differs from all congeners whose calls have been reported, except for $K$. baluensis and $K$. yongi, with short unpulsed notes emitted intermittently.
\end{abstract}

Key words: Advertisement call; Borneo; Kalophrynus; New species; Taxonomy

\section{INTRODUCTION}

The Oriental microhylid genus Kalophrynus Tschudi, 1838, occurs widely from Southern China to Java, the Philippines, and Assam, India and consists of small-sized terrestrial frogs that inhabit among leaf litters of the forest floor. The genus is small, with about 19 species, and accounts for only $3 \%$ of the family Microhylidae Günther, 1858 (Frost, 2011; Matsui et al., 2011a,b), but constitutes a distinct subfamily Kalophryninae Mivart, 1869. Notwithstanding this low species diversity, their classification has been sometimes confused, because some species of Kalophrynus are very similar to each other in morphology (e.g., Inger, 1966). The results of more recent acoustic and molecular analyses (e.g., Matsui et al., 1996, 2011a), how-

\footnotetext{
* Corresponding author. Tel/Fax: +81-75-7536846;

E-mail address: fumi@zoo.zool.kyoto-u.ac.jp
}

ever, indicated validity of some taxa that have been synonymized with the others.

Inger (1966) revised the genus and listed five species from Borneo. Four additional species have since been described (Dring, 1984; Kiew, 1984; Das and Haas, 2003; Dehling, 2011), but another, undescribed species is still present on this island. During a survey of northeastern Sarawak, northwestern Borneo, we heard calls of a Kalophrynus in 2008, and succeeded in collecting specimens in 2009 and 2010, from Bario in the Kelabit Highlands, where several herpetological collecting has been conducted in recent years (Zainudin, 1998; Das and Haas, 2003; Das, 2005). The call of this species was similar to the calls of some Kalophrynus reported to date (Malkmus and Riede, 1996; Matsui, 2009), but later close examination proved that the species in question is different not only morphologically but also genetically from all known congeners. Thus we describe it as a new species. 


\section{MATERIALS AND METHODS}

We recorded frog calls in the field using digital recorders (Zoom H2 and Olympus LS-10), and measured air temperature at the time of recording with a quick-recording thermostat thermometer (Takara A 600). Calls recorded were analyzed with the SoundEdit Pro (MacroMind-Paracom, Inc) software packages on a Macintosh computer, as described elsewhere (Matsui, 1997).

After taking tissues for phylogenetic analyses, specimens were fixed in $10 \%$ formalin, preserved in $70 \%$ ethanol, and are stored in Sarawak Museum (SM) and Graduate School of Human and Environmental Studies, Kyoto University (KUHE).

We took 18 body measurements following Matsui (1984): 1) snout-vent length (SVL); 2) head length (HL); 3) snout length (SL); 4) nostril-eye distance (N-EL); 5) eye length (EL, including upper eyelid, not superficial eyeball diameter); 6) tympanum-eye length (T-EL); 7) tympanum diameter (TD); 8) head width (HW); 9) internarial distance (IND); 10) interorbital distance (IOD); 11) upper eyelid width (UEW); 12) lower arm and hand length (LAL, from elbow to tip of third finger); 13) forelimb length (FLL); 14) tibia length (TL); 15) foot length (FL); 16) hindlimb length (HLL); 17) inner metatarsal tubercle length (IMTL); and 18) first toe length (1TL, from distal end of inner metatarsal tubercle to tip of first toe). We made all measurements to the nearest $0.05 \mathrm{~mm}$ with dial calipers under a binocular dissecting microscope. For the description of toe-webbing states we follow Savage (1975).

For morphological comparisons, we examined specimens of Kalophrynus stored at KUHE; The Natural History Museum, London (BM); Museo Civico di Storia Naturale, Genova (MSNG); National Museum of Natural History (Naturalis), Leiden (=Rijksmuseum van Natuurlijke Historie Leiden, RMNH); and Forschungsinstitut und Naturmuseum Senckenberg, Frankfurt am Main (SMF).

We examined the mitochondrial DNA genes $12 \mathrm{~S}$ and 16S rRNA from two male paratypes together with nine congeneric species. Methods of DNA preparation and data analyses are as reported in Matsui et al. (2011a).

\section{SYSTEMATICS}

Kalophrynus barioensis sp. nov.

(Figs. 1-3)

\section{Holotype}

SM.MU455.16 (formerly KUHE 53127), adult male from Jln. Arul Dalan trail to New Dam, Bario, State of Sarawak, Malaysia $\left(03^{\circ} 45^{\prime} \mathrm{N}, 115^{\circ} 26^{\prime} \mathrm{E}, 1141 \mathrm{~m}\right.$ asl), collected by Kanto Nishikawa on 18 August 2009.

\section{Paratypes}

KUHE 53125, 53126, two adult males data same as the holotype; KUHE 53128, 53129, two adult males locality same as the holotype, collected on 19 August 2010 by Kanto Nishikawa; KUHE 53571, an adult female from the same locality as the holotype, collected on 13 August 2010 by Koshiro Eto.

\section{Etymology}

The specific epithet is derived from Bario, a town in the Kelabit Highlands in Sarawak, northwestern Borneo, where this species occurs.

\section{Diagnosis}

A small-sized species that can be distinguished from all congeneric species by the following combination of characters; adult males 17.5-19.8 mm SVL $($ mean=18.5, $\mathrm{n}=5)$ and adult female $20.5 \mathrm{~mm} \mathrm{SVL}(\mathrm{n}=1)$; third toe longer than fifth; projection of fourth finger from palm shorter than length of terminal phalanx of third finger; subarticular tubercles under fourth finger and fifth toe absent, and usually absent under first finger; indistinct gland dorsal to arm insertion; no nuptial pads or asperities; forelimb without a humeral spine in males; outer metatarsal tubercle absent; light lateral stripe; usually with distinct inguinal dark spot without white rim or spotting; call consisted of a short, unpulsed note emitted intermittently with a long note gap. 


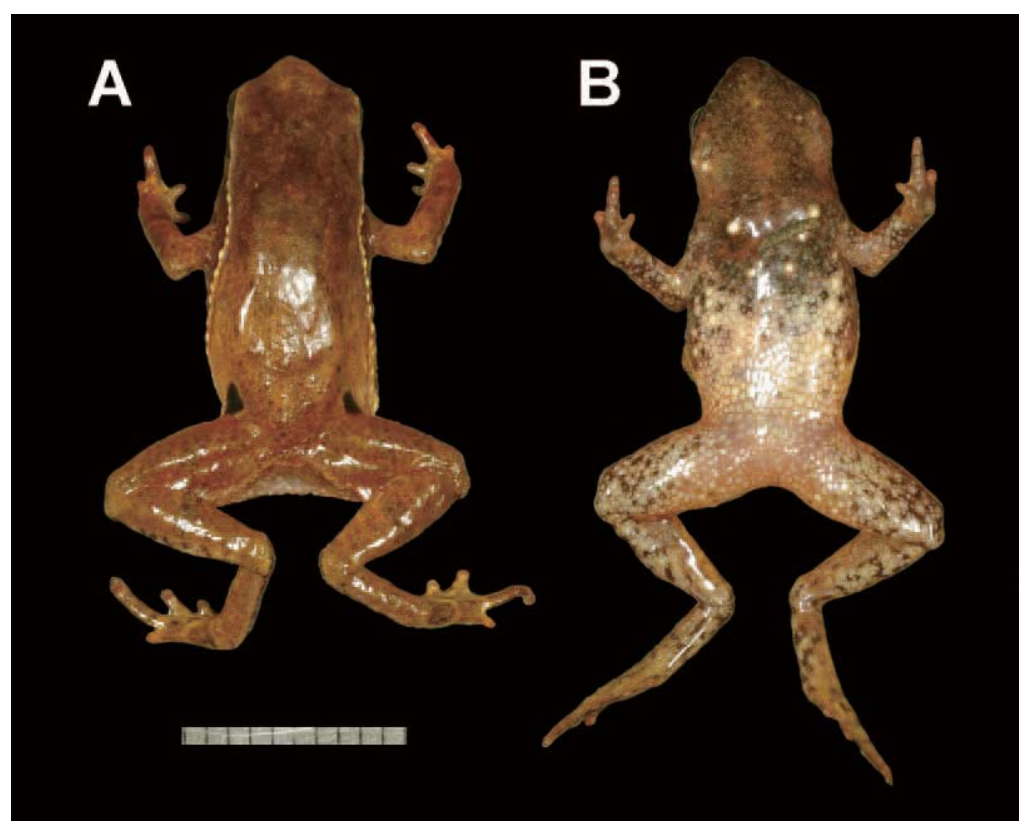

FIG. 1. (A) Dorsal and (B) ventral views of the male holotype of Kalophrynus barioensis sp. nov. (SM.MU455.16). Scale bar, $10 \mathrm{~mm}$.

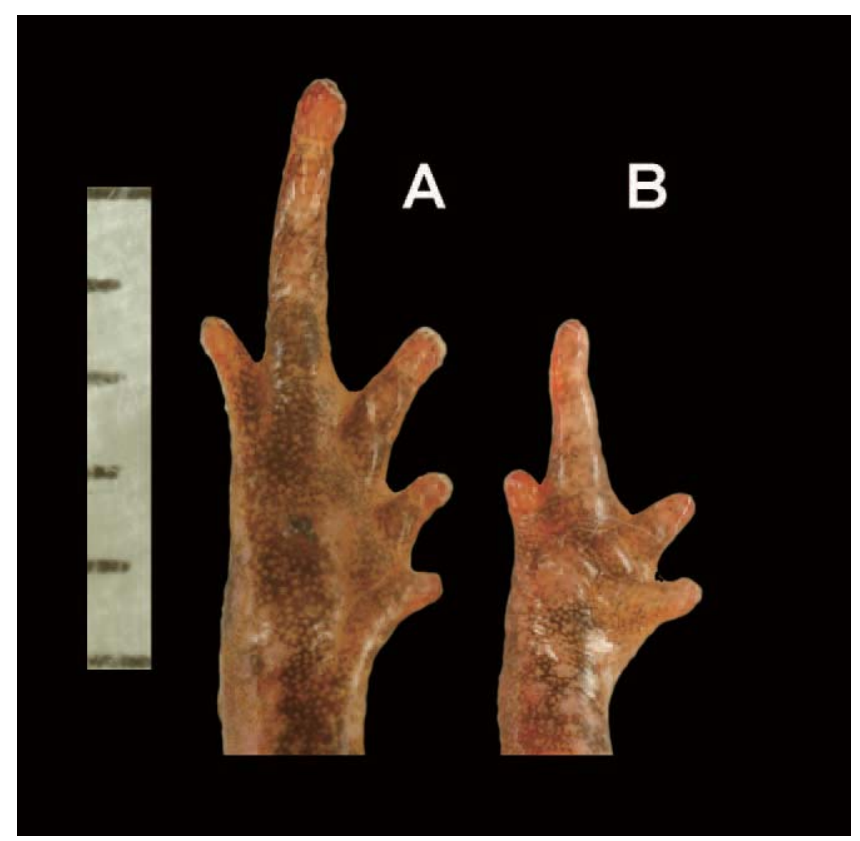

FIG. 2. Ventral views of (A) foot and (B) hand of the male holotype of Kalophrynus barioensis sp. nov. (SM.MU455.16). Scale bar, $5 \mathrm{~mm}$. 


\section{Description of holotype (measurements in $\mathrm{mm}$ )}

Small sized (SVL 17.5); habitus stocky; head triangular, slightly longer (6.3) than wide (6.2); snout bluntly pointed dorsally, pointed in profile, projecting beyond lower jaw; eye longer (2.8) than snout (2.4); canthus rostralis not sharply defined, straight; loreal region vertical, very slightly concave; nostril below canthus rostralis, directed laterally, closer to tip of snout (0.9) than to eye (1.2); interorbital distance (2.2) much wider than internarial distance (1.7), the latter larger than upper eyelid (1.3); pineal spot absent; tympanum not very distinct, diameter (1.3) less than one-half that of eye, and very close to eye $(0.2)$; upper jaw edentate; tongue entire, without papillae; crenulated ridges of skin on palate posterior to eye; a median, subgular vocal sac; long slit-like vocal openings on both sides of mouth floor.

Forelimb long (11.0); fingers thick, all basally slightly webbed; tips rounded, not dilated; relative length of fingers: IV $<$ I $<$ II $<$ III; portion of fourth finger projecting from palm (0.6) shorter than length of terminal phalanx of third finger (0.8); outer palmar tubercle large (1.0) and fleshy, inner indistinct; subarticular tubercles between finger tip and palmer tubercle rounded and indistinct, one on finger II and two on III (Fig. 2B); humeral spine absent.

Hindlimb moderately long (22.1) and slender; tibia moderately long (8.0), heels not overlapping when folded limbs held at right angles to body; tibiotarsal articulation of adpressed limb reaching to the center of tympanum when held alongside body; foot (6.6) much shorter than tibia; toe tips rounded; relative length of toes: I $<$ V $<$ II $<$ III $<$ IV; webbing poorly developed (Fig. 2A), formula: I $1 / 2^{-1} \frac{1}{2}$ II $1 / 2-2$ III $1^{1} / 2^{-}$ $3^{1 / 2}$ IV $3^{1 /} 2^{-1 / 2} \mathrm{~V}$; subarticular tubercles indistinct, numbering one on second toe, two on third toe, and three on fourth toe; no subarticular tubercles on first and fifth toes; inner metatarsal tubercle indistinct oval, length (0.9) shorter than first toe length (1.0); no outer metatarsal tubercle (Fig. 2A).

Skin dorsally smooth, scattered with very small tubercles (Fig. 1A); an indistinct gland on side of head behind tympanum, feebly

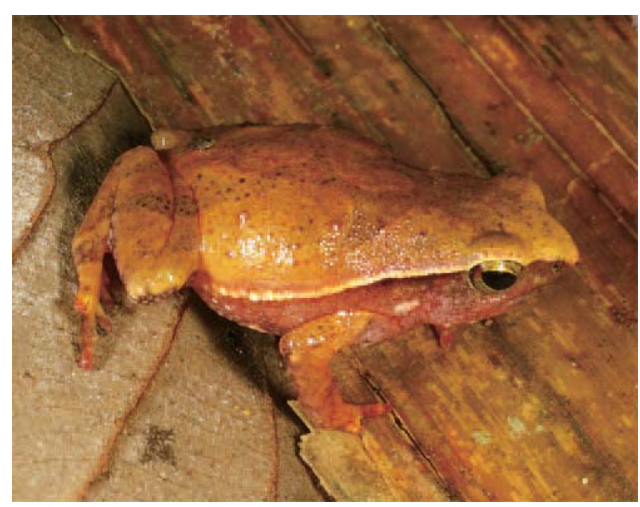

FIG. 3. Dorsolateral view of a male paratype of Kalophrynus barioensis sp. nov. (KUHE 53125) from Bario, Kelabit Highlands, Sarawak.

delimited by a sinuous groove; a raw of round tubercles dorsolaterally from posterior margin of upper eyelid to groin; minute tubercles along margin of lower jaw and on flank; large subconical tubercles on chest (Fig. 1B); chin, abdomen, and posteroventral side of thigh with flattened glandules; inner and outer margins of fourth finger without skin fringes; nuptial pads absent.

\section{Color}

In life, ground color of dorsum orange brown, with obscure hour-glass shaped brown marking from upper eyelid to shoulder; a light cream dorsolateral line extending from anterior margin of upper eyelid to groin, forming a boundary between lighter dorsum and darker sides of flank fusing with brownish sides of head and shoulder; limbs with obscure dark cross bars (Figs. 1A,3); chin and chest dark brown, with obscure dirty cream bands medially and laterally; abdomen cream scattered with black spots anteriorly; large tubercles on chest and minute tubercles along margin of lower jaw and on flank cream; ventral side of limbs pinkish gray dotted with dark brown (Fig. 1B); inguinal spot entirely black without lighter borders or pattern; iris greenish golden. In preservative, color and pattern have generally faded but not obviously changed. 


\section{Variation}

Individuals of the type series are generally similar in morphology (Table 1). A single female $(\mathrm{SVL}=20.5 \mathrm{~mm})$ is larger than five males (17.5-19.8 mm). In two males (KUHE 53126 and 53129), head is wider than long, and in one male (KUHE 53125), snout is slightly longer than eye. Subarticular tubercles are generally indistinct, and each one tubercle on the second and third toes are nearly absent in two males (KUHE 53125 and 53129), while the trace of one tubercle is discernible on the first finger of left hand in one male (KUHE 53126), and one additional tubercle is traceable on the third fingers of the female (KUHE 53571). Web formula slightly varies among individuals and a male (KUHE 53125) had I $1 / 2^{-2}$ II $1-2^{1 / 2}$ III $2-3^{1 / 2}$ IV $3-1 / 2$ V. The inguinal black spot is lacking on the right side in one individual (KUHE 53125).

\section{Range}

Known only from the type locality, around the hills of Bario, Kelabit Highlands, Sarawak, Eastern Malaysia.

\section{Natural history}

Males of the type series of $K$. barioensis were found calling in narrowly scattered cho- ruses along trails at the edge of secondary broad-leaf and bamboo forests. Calling males hid themselves among dead leaves and were very difficult to locate, but responded to playback of recorded calls.

At the type locality, there were no large bodies of water, and eggs and larvae have never been found. However, August seems to be within the breeding season, as evidenced by calls of males heard in three years of our survey from middle to late August. Calls were heard from daytime to early evening (from $930 \mathrm{~h}$ to $2100 \mathrm{~h}$ ) whether or not it rained. A single female collected in mid August had fully developed ova in ovaries. Two ova have diameters of 0.80 and $0.87 \mathrm{~mm}$, with pale brown animal hemisphere and cream vegetal hemisphere.

The associated anuran species were Philautus mjobergi Smith, 1925 and Philautus cf. kerangae Dring, 1987, whose calls were heard from trees in the surrounding forests.

\section{Call characteristics}

We recorded the calls of a $K$. barioensis at the type locality on 19 August 2009 (air temperature $24.6 \mathrm{C}$ at $1520 \mathrm{~h}$ ). The advertisement call (Fig. 4) was a soft 'ting', and emitted intermittently with a note gap of 2.9

TABLE 1. Measurements of 18 characters in five males and one female of Kalophrynus barioensis. SVL $(\overline{\mathrm{x}} \pm 1 \mathrm{SD}$, in $\mathrm{mm})$ and medians of ratios $(\mathrm{R})$ of other characters to SVL, followed by ranges in parenthesis. See text for character abbreviations.

\begin{tabular}{|c|c|c|c|c|c|c|}
\hline & SVL & RHL & RHW & RIND & RIOD & RUEW \\
\hline Male $(n=5)$ & $\begin{array}{c}18.5 \pm 1.04 \\
(17.5-19.8)\end{array}$ & $\begin{array}{c}35.3 \\
(34.0-35.8)\end{array}$ & $\begin{array}{c}35.3 \\
(34.4-37.7)\end{array}$ & $\begin{array}{c}9.4 \\
(9.1-10.1)\end{array}$ & $\begin{array}{c}12.8 \\
(12.3-14.4)\end{array}$ & $\begin{array}{c}7.5 \\
(5.4-8.3)\end{array}$ \\
\hline Female $(n=1)$ & 20.5 & 33.1 & 32.6 & 9.1 & 11.3 & 8.7 \\
\hline & RSL & REL & RN-EL & RTD & RT-EL & RLAL \\
\hline Male $(n=5)$ & $\begin{array}{c}13.8 \\
(11.4-16.1)\end{array}$ & $\begin{array}{c}15.9 \\
(15.2-16.1)\end{array}$ & $\begin{array}{c}6.9 \\
(5.7-7.6)\end{array}$ & $\begin{array}{c}7.2 \\
(4.7-7.9)\end{array}$ & $\begin{array}{c}1.2 \\
(0.6-1.4)\end{array}$ & $\begin{array}{c}45.5 \\
(44.6-49.7)\end{array}$ \\
\hline Female $(n=1)$ & 15.9 & 20.5 & 6.8 & 9.5 & 1.0 & 44.8 \\
\hline & RFLL & RTL & RFL & RHLL & RIMTL & R1TOEL \\
\hline Male $(n=5)$ & $\begin{array}{c}56.7 \\
(55.8-63.1)\end{array}$ & $\begin{array}{c}42.8 \\
(42.2-46.9)\end{array}$ & $\begin{array}{c}35.1 \\
(33.5-37.5)\end{array}$ & $\begin{array}{c}136.7 \\
(126.2-140.8)\end{array}$ & $\begin{array}{c}3.8 \\
(2.5-4.9)\end{array}$ & $\begin{array}{c}4.9 \\
(4.0-5.9)\end{array}$ \\
\hline Female $(n=1)$ & 60.0 & 43.5 & 32.6 & 136.0 & 4.1 & 5.7 \\
\hline
\end{tabular}




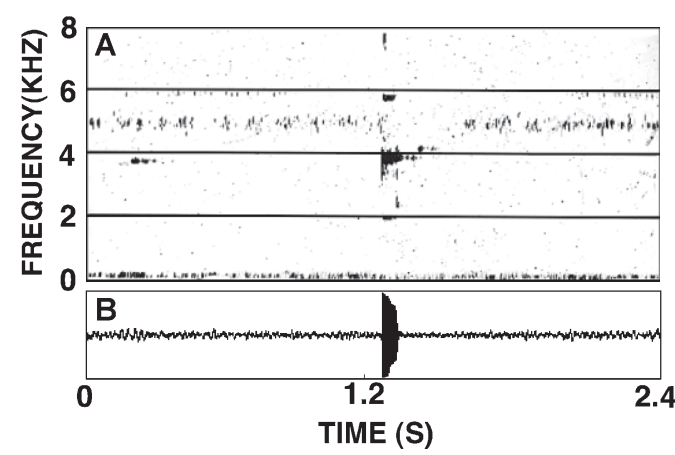

FIG. 4. Sonagram (A) and wave form (B) showing a note of an advertisement call of Kalophrynus barioensis sp. nov. from Bario, Kelabit Highlands, Sarawak, recorded at an air temperature $24.6 \mathrm{C}$.

$5.6 \mathrm{~s}(\overline{\mathrm{x}} \pm \mathrm{SD}=3.61 \pm 0.56 \mathrm{~s}, \mathrm{n}=12)$ and note repetition rate of $0.21-0.34$ per $\mathrm{s}(\overline{\mathrm{x}} \pm \mathrm{SD}=$ $0.28 \pm 0.04$ per $s, n=12$ ). It consisted of a short, unpulsed note and lasted about 68$77 \mathrm{~ms}(\overline{\mathrm{x}} \pm \mathrm{SD}=72.9 \mathrm{~ms} \pm 2.7, \mathrm{n}=13)$. At least six clear harmonics were evident, and the first harmonic was $1800-1950 \mathrm{hz}(\overline{\mathrm{x}} \pm \mathrm{SD}=1907.7 \pm$ $53.4 \mathrm{hz}, \mathrm{n}=13$ ). The dominant frequency was the second harmonic, and the initial frequency of $3600-3800 \mathrm{hz}(\overline{\mathrm{x}} \pm \mathrm{SD}=3750 \pm 70.7 \mathrm{hz}, \mathrm{n}=$ 13) slightly rose to end at about $3650-3900 \mathrm{hz}$ $(\overline{\mathrm{x}} \pm \mathrm{SD}=3800 \pm 76 \mathrm{hz}, \mathrm{n}=13)$. The third and fourth harmonics were $5475-5750 \mathrm{hz}(\overline{\mathrm{x}} \pm \mathrm{SD}=$ $5638.5 \pm 82.7 \mathrm{hz}, \mathrm{n}=13$ ) and $7300-7700 \mathrm{hz}$ $(\overline{\mathrm{x}} \pm \mathrm{SD}=7553.8 \pm 105.0 \mathrm{hz}, \mathrm{n}=13)$, respectively.

\section{Comparisons}

Kalophrynus barioensis with SVL in males of $17.5-19.8 \mathrm{~mm}$ and in a female of $20.5 \mathrm{~mm}$ can be differentiated from nine known Bornean species in the following way (data from Inger, 1966; Matsui, 2009; Dehling, 2011; Matsui et al., 2011b; Matsui, unpublished). The new species overlaps in size with $K$. nubicola Dring, 1984 (SVL=14.4-24.4 mm), but differs from it by the possession of at least several subarticular tubercles of fingers and toes (indistinct or absent in K. nubicola); The new species differs from all the other Bornean species by smaller body size and following characteristics: from K. subterrestris Inger, 1966 (21.0-23.4 mm) by the lack of distinct subarticular tubercle on the fourth finger and outer metatarsal tubercle (a single subarticular tubercle and outer metatarsal tubercle present in $K$. subterrestris); from $K$. heterochirus Boulenger, 1900 (SVL= $24.4 \mathrm{~mm}$ in a female syntype) by the lack of white spots in a black inguinal marking (present in K. heterochirus); from K. eok Das and Haas, $2003(26.3 \mathrm{~mm})$ by the lack of subarticular tubercles on fourth finger and fifth toe (with single subarticular tubercle on fourth finger and two subarticular tubercles on fifth toe in $K$. eok); from $K$. punctatus Peters, $1871(28.3 \mathrm{~mm})$ by the fifth toe, not projecting as far as or farther than the third toe (fifth toe longer than the third toe in $K$. punctatus); from K. calciphilus Dehling, 2011 (29.7$30.1 \mathrm{~mm}$ ) by lacking outer metatarsal tubercle and having dorsolateral stripe without black margin dorsally (prominent tubercle present, dorsolateral stripe bordered by black on both margins in K. calciphilus); from K. baluensis Kiew, 1984 (34.8-39.0 mm) by the lack of distinct dorsal marking and having black inguinal marking (usually with clear dark markings on dorsum and yellow inguinal marking in $K$. baluensis); from $K$. pleurostigma Tschudi, 1838 (35.0-50.4 mm) by having the fourth finger from palm shorter than length of the terminal phalanx of third finger, and lack of nuptial pads in males (fourth finger longer than terminal phalanx of third finger, and with nuptial pads in $K$. pleurostigma); and from $K$. intermedius Inger, 1966 $(37.9-40.5 \mathrm{~mm})$ by the possession of light lateral stripe and inguinal black marking (stripe and marking absent in $K$. intermedius).

Of the 10 species occurring outside of Borneo, two are smaller or of similar size to $K$. barioensis. From K. robinsoni Smith, 1922 $(16.8 \mathrm{~mm})$, the new species differs in the absence of spinous nuptial pads in the males (present in $K$. robinsoni); and from $K$. menglienicus Yang and $\mathrm{Su}, 1980$ (19.8$23.4 \mathrm{~mm}$ ) by the possession of distinct tympanum and toe webbing (tympanum concealed and toe webbing absent in $K$. menglienicus). Kalophrynus barioensis is smaller than all the 
other species and further differs: from $K$. bunguranus (Günther, 1895) (20.7-22.8 mm) by the lack of light marking surrounding black inguinal mark (black inguinal marking in a light area in K. bunguranus); from Kalophrynus sp. from Peninsular Malaysia (Matsui et al., 2011b, 26.2-28.7 mm) by normal-shaped snout and one subarticular tubercles indistinct or absent on fourth finger (snout directed downwards and two subarticular tubercles on fourth finger in Kalophrynus sp.); K. yongi Matsui, 2009 (28.8-31.0 mm) by having a normal humerus (strongly developed terminal ridges on humerus, and related skin modification in K. yongi); from K. palmatissimus Kiew, $1984(31.2-38.8 \mathrm{~mm})$ by poorly developed webbing on the fourth toe (well-developed webbing in $K$. palmatissimus); from $K$. minusculus Iskandar, 1998 (32.2 $\mathrm{mm})$ by the fourth finger shorter than length of the terminal phalanx of third finger, and the lack of distinct dorsal marking (fourth finger longer than the terminal phalanx of third finger, and usually with clear dark markings on dorsum in $K$. minusculus); from $K$. orangensis Dutta, Ahmed, and Das, 2000 (35-38 mm) and from $K$. interlineatus (Blyth, 1855) (37.4-47.7 mm) by the fourth finger shorter than length of the terminal phalanx of third finger (fourth finger longer than terminal phalanx of third finger in $K$. orangensis and K. interlineatus); and from K. stellatus Stejneger, 1908 (35.0-45.0 mm) by the lack of nuptial pads in males (present in K. stellatus).

Of calls of seven species of Kalophrynus been analyzed ( $K$. baluensis [Malkmus and Riede, 1996]; K. calciphilus [Dehling 2011]; $K$. interlineatus [Matsui et al., 1996]; K. nubicola [Dring, 1984]; K. pleurostigma [Matsui et al., 1996]; K. yongi [Matsui, 2009]; and Kalophrynus sp. from Peninsular Malaysia [Matsui et al., 2011b]), those of $K$. calciphilus, $K$. interlineatus, $K$. nubicola, $K$. pleurostigma, and Kalophrynus sp. sharply differ from the call of $K$. barioensis with unpulsed short notes. In this respect, $K$. barioensis resembles $K$. baluensis and $K$. yongi, but the dominant frequency is much higher $(3600-3900 \mathrm{hz})$ than these species $(2600 \mathrm{hz}$ in $K$. baluensis [Malkmus and Riede, 1996] and $1531 \mathrm{hz}$ in $K$. yongi [Matsui, 2009]). These differences are not ascribed to different body size or temperatures at the time of recording, and should be regarded as specific ones.

Finally, the uncorrected pairwise sequence divergences in $879 \mathrm{bp}$ of mitochondrial $16 \mathrm{~S}$ rRNA gene between $K$. barioensis and the nine congeners ( $K$. baluensis, $K$. cf. heterochirus from Matang, Sarawak, $K$. interlineatus, K. palmatissimus, K. pleurostigma, K. stellatus, K. subterrestris, K. yongi, and Kalophrynus sp. from Peninsular Malaysia) are as large as 4.3-9.1\%.

\section{DISCUSSION}

We heard calls of $K$. barioensis in almost all hill forests around Bario that we visited but could not find eggs or larvae as noted above. Das and Haas (2003) reported that a male of another congener from the Kelabit Highlands, $K$. eok, was found calling from a water-filled node of a fallen bamboo stalk. These species are suspected to have phytotelmic breeding preference like some congeners (Lim and Ng, 1991; Matsui, 2009). Abundance in the type locality of $K$. barioensis of two species of Philautus that develop directly without large bodies of water seems to support this assumption.

Becoming aware of unfamiliar frog calls has led trained researchers to find out new and/or cryptic species (e.g., Philautus kerangae Dring, 1987: Dring, 1987; Hylarana laterimaculata [Barbour and Noble, 1916]: Leong et al., 2003; Leptolalax melanoleucus Matsui, 2006 and L. fuliginosus Matsui, 2006: Matsui, 2006; $L$. kecil Matsui, Belabut, Ahmad, and Yong, 2009: Matsui et al., 2009; Kalophrynus sp.: Matsui et al., 2011b). The presence, or occasionally relative abundance, of some frogs in a given locality can be confirmed by their calls, and acoustic information is thus very important in taxonomic and ecological studies.

In the case of present new species, $K$. barioensis, however, the situation slightly differs. 
When we first heard voices of this species, we imagined that the calls were those of $K$. cf. heterochirus, which widely occurs in Sarawak (Matsui, unpublished data), K. baluensis from Mt. Kinabalu, Sabah, or K. yongi from Cameron Highlands, Peninsular Malaysia. This is because calls of these species consist of unpulsed short notes, and are very similar to the human ear. Actual collection and examination of the species, however, revealed distinct specific status of the Kalophrynus from Bario. This exemplifies that frogs that emit calls similar to those of the others require special cautions in their identification. In relation to this, it is interesting that $K$. eok seems to emit calls similar to $K$. barioensis. According to Das and Haas (2003), the call of $K$. eok was described as a single, low-pitched note, emitted about every $3 \mathrm{~s}$. Thus, by simply hearing calls alone may not differentiate the two species.

Long ago, the herpetofauna of Kelabit Highlands, especially that of Gunung Murud, was intensively studied (Smith, 1925), since then very little study has occurred. Now, $K$. pleurostigma, $K$. eok, and the new species, $K$. barioensis are known from regions around Bario (Das and Haas, 2003; Zainudin, 1998). However, through more intensive studies, the anuran fauna, including Kalophrynus, would increase in future, and acoustic information, if properly used will play a great role in elucidating biodiversity of the Kelabit Highlands.

\section{ACKNOWLEDGMENTS}

The field survey in Sarawak was made under research permits NPW.907.4.2 (III)-68 and NCCD.907.4.4(V)-93 from the Forest Department, Sarawak. The Sarawak Forestry Corporation and the Sarawak Biodiversity Centre kindly provided facilities for conducting research. We are grateful to the following for their encouragements and/or permission to conduct research and/or field companionship: Haji ali Bin Yusop, Lucy Chong, Koshiro Eto, Takao Ichioka, Het Kalian, Marker Nyogin, Mohd. Shabudin Sabki, Uning, and Haji Abang Mohamad Mohtar Bin Abang Pawo- zan. We are also indebted to A. Hamidy for laboratory assistance, and to Colin McCarthy and Barry T. Clarke (BM), Giuliano Doria (MSNG), Marinus Hoogmoed (RMNH), and Gunther Koehler (SMF), for allowing the senior author to examine specimens under their care. Field trips were made possible by grants from The Monbusho International Scientific Research Programs and from The Monbusho through the Japan Society for the Promotion of Science (Field Research, Nos. 10041166 and 20405013) to the senior author. We thank Sean Otani for reviewing English text.

\section{LITERATURE CITED}

DAS, I. 2005. A new species of Polypedates (Anura: Rhacophoridae) from Gunung Murud, Sarawak (Northwestern Borneo). The Raffles Bulletin of Zoology 53: 265-270.

DAS, I. AND HAAS, A. 2003. A new species of Kalophrynus (Anura: Microhylidae) from Central Borneo. The Raffles Bulletin of Zoology 51: 113-117.

DEHLING, J. M. 2011. A new karst-dwelling species of Kalophrynus (Anura: Microhylidae) from Gunung Mulu National Park, Borneo, Malaysia. Zootaxa 2737: 49-60.

DRING, J. C. M. 1984 (1983). Some new frogs from Sarawak. Amphibia-Reptilia 4: 103-115.

DRING, J. C. M. 1987. Bornean treefrogs of the genus Philautus (Rhacophoridae). AmphibiaReptilia 8: 19-47.

Frost, D. R. 2011. Amphibian species of the world: an online reference. Version 5.5 (31 January, 2011). American Museum of Natural History, New York. http://research.amnh.org/vz/herpetology/ amphibia/index.html

INGER, R. F. 1966. The systematics and zoogeography of the Amphibia of Borneo. Fieldiana: Zoology 52: 1-402.

KIEW, B.-H. 1984. A new species of frog (Kalophrynus baluensis n. sp.) from Mount Kinabalu, Sabah, Malaysia. Malayan Nature Journal 38: 151-156.

LEONG, T. M., MATSUI, M., YONG, H.-S., AND HAMID, A. A. 2003. Revalidation of Rana laterimaculata Barbour et Noble, 1916 from synonymy of Rana baramica Boettger, 1901. Current Herpetology 22: 17-27.

LIM, K. K. P. AND NG, P. K. L. 1991. Nepenthiphil- 
ous larvae and breeding habits of the sticky frog, Kalophrynus pleurostigma Tschudi (Amphibia: Microhylidae). Raffles Bulletin of Zoology 39: 209-214.

MALKMUS, R. AND RIEDE, K. 1996. Zur Bioakustik von Megophrys baluensis (Boulenger, 1899) und Kalophrynus baluensis Kiew, 1984, zweier seltener Froscharten aus Borneo (Anura: Pelobatidae, Microhylidae). Herpetozoa 9: 151-155.

MATSUI, M. 1984. Morphometric variation analyses and revision of the Japanese toads (genus Bufo, Bufonidae). Contributions from the Biological Laboratory, Kyoto University 26: 209428.

MATSUI, M. 1997. Call characteristics of Malaysian Leptolalax with a description of two new species (Anura: Pelobatidae). Copeia 1997: 158165.

MATSUI, M. 2006. Three new species of Leptolalax from Thailand (Amphibia, Anura, Megophryidae). Zoological Science 23: 821-830.

MATSUI, M. 2009. A new species of Kalophrynus with a unique male humeral spine from Peninsular Malaysia (Amphibia, Anura, Microhylidae). Zoological Science 26: 579-585.

MATSUI, M., CHAN-ARD, T., AND NABHITABHATA, J. 1996. Distinct specific status of Kalophrynus pleurostigma interlineatus (Anura, Microhylidae). Copeia 1996: 440-445.

MATsui, M., Belabut, D. M., Ahmad, N., AND YONG, H.-S. 2009. A new species of Leptolalax (Amphibia, Anura, Megophryidae) from Peninsular
Malaysia. Zoological Science 26: 243-247.

Matsui, M., Hamidy, A., Daicus, M. B., Norhayati, A., PANHA, S., Sudin, A., KHONSUE, W., OH, H.-S., YONG, H.-S., JiANG, J.-P., AND NisHIKAWA, K. 2011a. Systematic relationships of Oriental tiny frogs of the family Microhylidae (Amphibia, Anura) as revealed by mtDNA genealogy. Molecular Phylogenetics and Evolution 61: 167-176.

Matsui, M., Nishikawa, K., Belabut, D. M., Norhayati, A., AND Yong, H.-S. 2011b. A new species of Kalophrynus (Amphibia, Anura, Microhylidae) from Southern Peninsular Malaysia. Zootaxa: in press

SaVAGE, J. M. 1975. Systematics and distribution of the Mexican and Central American stream frogs related to Eleutherodactylus rugulosus. Copeia 1975: 254-306.

SMith, M. A. 1925. On a collection of reptiles and amphibians from Mt. Murud, Borneo. Sarawak Museum Journal 3: 5-14.

ZAINUDIN, R. 1998. A brief note on frogs of Bario, Kelabit Highlands, Sarawak. P. 201-206. In: G. Ismail and L. bin Din (eds.), A Scientific Journey through Borneo. Bario. The Kelabit Highlands of Sarawak. Pelanduk Publications, Kuala Lumpur.

Accepted: 12 November 2011 